\title{
Otomobil Koltuklarını Isıtmak İçin Yeniden Tasarlanan Standart Otomobil Klima Sisteminin Performansının Bulanık Mantık ile Modellenmesi
}

\author{
${ }^{1}$ Ali Ateş, ${ }^{1}$ Kevser Dinçer, ${ }^{1}$ Eyüb Canl1, ${ }^{2}$ Sadık Ata \\ ${ }^{1}$ Selçuk Üniversitesi, Makine Mühendisliği Bölümü, Konya, Türkiye \\ ${ }^{2}$ Konya Ticaret Odası Karatay Üniversitesi, Makine Mühendisliği Bölümü, Konya, Türkiye
}

\begin{abstract}
Özet
$\mathrm{Bu}$ çalışma, deneysel bir çalışmadan elde edilen veriler kullanılarak taşıt koltuklarının 1sıtıllması için değiştirilen bir taşıt kliması sisteminin performansının bulanık mantık modelini sunar. Deneyler sırasında 500 dev/dak değerinden $1600 \mathrm{dev} /$ dak değerine kadar $100 \mathrm{dev} /$ dak aralıklarla değişen kompresör devirlerine karşllık koltuk oturak ve sırt sıcaklıkları 15 dakika boyunca kaydedilmiştir. Bulanık mantık yönteminde, giriş parametreleri kompresör devri ve zaman olarak seçilmişken çıkış parametreleri olarak koltuk sırt ve oturak sıcaklıkları seçilmiştir. Bulanıklaştırma işlemi için on iki hız seviyesi ve on zaman seviyesi belirlenmiştir. Çıkış için yedi sırt sıcaklığı ve on bir oturak sıcaklığı seçilmiştir. Sistemin giriş ve çıkışının ilişkisini tanımlayan toplamda 120 gözetim kuralı saptanmıştır. Toplamda 4320 sırt ve oturak sıcaklık verisi ayrıca bulanık mantık ile bulunmuştur. Bulanık mantık ve deneysel sonuçların birbirleri ile karş̧laş̧ırırlmasında "determinasyon katsayısı" kullanılmıştır. Deneysel çalışmanın ara değerleri bulanık mantık modeli ile de tahmin ettirilmiştir. Canlı denekten koltuğa gerçekleşen 1Sı transferi nedeniyle isıl süreç içerisinde koltuk yüzeylerindeki azami sıcaklık değeri 5inci ve 10uncu dakikalar arasında gerçekleşmiştir. En yüksek sıcaklık değerleri $1600 \mathrm{dev} / \mathrm{dak}$ değerinde elde edilirken en düşük sıcaklık değerleri $500 \mathrm{dev} / \mathrm{dak}$ değerinde elde edilmiştir. Deneysel veriler ile model sonuçları arasındaki korelasyon tatmin edicidir. Sonuç olarak bulanık mantık taşıt ısıl konfor sistemlerinde hızlı karar alma için uygun bir araç olarak bulunmuştur. Model gelecekte bir akıllı araç klima sistemine adapte edilmek için değiştirilebilir. İlk defa sunulan bu deneysel veriler ile Bulanık Mantık uygulama sonuçları gelecek çalışmalar için referans teşkil etmektedir.
\end{abstract}

Anahtar kelimeler: Bulanık Mantık, Isıl performans, Taşıt kliması, Taşıt koltuk 1sıtması

\section{Modeling of Performance of a Standard Vehicle Air Conditioning System Re-Designed for Heating Vehicle Seats via Fuzzy Logic}

\begin{abstract}
This study presents Fuzzy Logic model of performance of a vehicle air conditioner system modified for heating vehicle seats by using data obtained from an experimental work. Back and seating temperatures of the seat were recorded for 15 minutes for compressor speeds ranging from $500 \mathrm{rpm}$ to $1600 \mathrm{rpm}$ with $100 \mathrm{rpm}$ intervals. Input parameters were selected as compressor speed and time while output parameters were back and seating surface temperatures of the vehicle seat for the Fuzzy Logic model. Twelve levels of revolution and ten levels of time were selected for the fuzzyfication process. Seven back temperature levels and eleven seat temperature levels were determined for output. Totally 120 supervision rules that define relation between system input and output were determined. The measured data that were yielding totally 4320 points for back and seating surfaces were also found by Fuzzy Logic. Determination coefficient was used for the comparison of experimental and fuzzy logic results. Surface temperatures were also estimated with fuzzy logic for intermediate values of the experimental data. The highest temperatures on the surfaces of the seat were observed between $5^{\text {th }}$ and $10^{\text {th }}$ minutes of the thermal process because of the heat transfer from the live test subject to the seat. The highest temperature was obtained for $1600 \mathrm{rpm}$ while the lowest temperature is obtained for $500 \mathrm{rpm}$. The correlation between model results and experimental data are satisfactory. As a conclusion, fuzzy logic is found a proper tool for rapid decision making in vehicle thermal comfort systems. The model can be modified in the future in order to be adapted into a smart vehicle thermal comfort system. The first time presented experimental data and their Fuzzy Logic application constitute a reference for the future works.
\end{abstract}

Keywords: Fuzzy Logic, Thermal performance, Vehicle air conditioner, Vehicle seat heating

Sorumlu Yazar: Selçuk Üniversitesi, Teknoloji Fakültesi, Makine Mühendisliği, Oda No:118, Selçuklu, Konya, TÜRKIYYE, E-mail:ecanli@ selcuk.edu.tr Tel. 00903322233352 / 


\section{Introduction}

Air conditioner (AC) unit is now a standard component of the passenger cars though it was a comfort choice in the beginnings. A lot of works were performed in order to improve the component features of the air conditioners. Conventional vehicle air conditioners work on the vapor compression cycle principles. Alternative air conditioner units have been being developed recently. The most promising features of these air conditioners are their low environmental impacts and utilization of the waste heat. Still there are things yet to be considered for technical advancement and one of them is the use of the ACs for indirect comfort purposes. This is one of the main goals of the present work.

Air conditioners are an important part of vehicles in respect of the thermal comfort. The parameters affecting thermal comfort can be listed as air temperature, air velocity, air humidity, average radiation amount, activities and clothing. Conventional vehicle air conditioner units in very hot or very cold days are incapable of maintaining thermal comfort of passengers and drivers for a certain period of time. Heating or cooling the vehicle cabin interior takes some time. Local heating and cooling can be applied in this time interval in order to provide instant comfort. There are instances of vehicle seat heating in winter seasons. However cooling vehicle seats in summer seasons are not encountered and are not common while it can be very important for thermal comfort. The response time of air conditioner units can be improved by this way and local application can reduce the thermal load on the AC.

A vehicle seat with heating/cooling features is more effective than the conventional AC. Time and energy loss can be avoided or reduced by equipping or extending $\mathrm{AC}$ components into vehicle seats with a relatively low initial cost. First $\mathrm{AC}$ is desired to be operated when one gets in a parked car with closed windows in hot days of summer months. Generally vehicle AC sends chilled air when its evaporator reaches to a certain temperature in such circumstances. The chilled air can cause health problems if the person in the car is in a sweaty condition. A thermal balance can be attained if the waist and calf of the person are cooled simultaneously with the frontal surface of the body by means of the vehicle seat cooling in the aid of AC. Similarly one would desire to get heated up when the vehicle cabin is cold in winter months as fast as it can be. An effective heat transfer can be realized through the calf by heating the cold surface of the seat and contribution can be made to the heating of the body by this way. These scenarios may contribute positively to the AC performance considering that they lead to an effective heating or cooling. Therefore it is of interest to manage temperature of seat surfaces by means of an AC.

Vehicle thermal comfort is still a presently hot topic for $R \& D s$ and research facilities. It comprises various systems ranging from controlling vehicle windows to ventilation and air conditioning systems. For instance, Mupit and Shafie [1] conducted an experimental study on automated control of the vehicle side windows and investigated the options in order to regulate the position of the windows considering the preset positions and current position. Although the study considers safety regulations and needs, it is obvious that control of the openings to the environment is a certain way of thermal comfort management. Another substantial example of HVAC system research utilizing a fuzzy controller was reported by Hamed and Alami [2]. They emphasized the nonlinearity of the HVAC systems that are used in multi-volume buildings and stressed the need of a rapid decision making controller for an efficient and low cost operation. The proposed controller in the work is capable of maintaining comfort conditions under time varying thermal loads. The name of the utilized method by the authors is called Adaptive Hierarchical Fuzzy and it consists of two levels, namely first fuzzy level (controlling air temperature and air quality) and the second fuzzy level (Controlling error and change of error that comes from first level). They found that the hierarchical fuzzy makes it easy to partition the controller and gives a better understand of controller running. Adaptive hierarchical fuzzy controller on the other hand can also preserve air quality beside the air temperature. Both abilities provide preferable comfort levels for the occupants.

While controlling surface temperatures of a vehicle seat by means of an AC is a purpose of this work, preparing a fast decision making tool for managing the AC is the another one. For this, Fuzzy Logic modeling was selected. It is a well known tool by now though it is not encountered in the literature that a Fuzzy Logic model for seat heating management is selected for the decision making or estimation.

Fuzzy Logic approach is a part of Machine Learning struggle. Machine learning is a common tool for engineers. It is used for interpolation, extrapolation, data engineering, decision making and such. Artificial Neural Networks, for example, is a good alternative of regression, especially when vast amount of data is in order. The work of Akıncıoğlu et al. [3] can be given as an instance of 
the method. They predicted thrust forces and hole diameters for AISI D2 steel with cemented carbide tools in drilling process. Another popular machine learning tool is Genetic Algorithm. Guler et al. [4] reported a fine study which contains a famous problem alongside with some alternative approaches to the usage of the Genetic Algorithm. Öztürk et al. [5], on the other hand, conducted a work on fuzzy neural network controller that can be treated as a hybrid approach in order to exploit advantages of both methods. Another tool they used was Particle Swarm Optimization (PSO). So it can be said that they used PSO in order to constitute a real time controller consisting of artificial neural network and fuzzy logic hybrid.

Fuzzy logic is a mathematical discipline depending on cluster theory [6]. Fuzzy logic works with intermediate values such as medium-long or shortmedium for evaluation instead of certain statements such as long or short [7].

Fuzzy logic model is also used for avoiding negative situations such as hard calculations due to existence of numerous independent variables and unknown intermediate values [8].

Finally alternative usage of vehicle ACs and therml comfort issues of the passengers in the literature should be mentioned here. Unal et al. [9] investigated coefficient of performance (COP) changing with mass flow rate theoretically for a new system that is constituted by modifying a vapor compression refrigeration cycle used in buses into a system with an ejector. Solmaz et al. [10] performed a $\mathrm{PhD}$ study investigating dynamic performance of a vehicle AC system supported by solar energy experimentally. Thermodynamic analysis of the AC system for five different cities of Turkey that is rich in terms of solar energy is analyzed. Erzurumlu and Sabanc1 [11] examined effects of $\mathrm{AC}$ on specific fuel consumption and efficiency of a tractor experimentally. AC usage in tractor acts positively on specific fuel consumption and negatively on tail shaft efficiency according to the work. Alkan and Hoşöz [12] conducted a comparative performance analysis for different compressor rpm values using two different types of expansion devices for a vehicle AC with R134a refrigerant in their study. They determined that TXV operation usually yields slightly higher cooling capacity. Öngel and Mergen [13] performed a study about the subject of providing satisfaction in human work environment and eliminating factors reducing performance of humans. They increased the factors that provide physical and mental efficiency increase by improving thermal comfort. Kılıç and Akyol [14] experimentally investigated continuously changing thermal comfort parameters in selection of different air ports during the heating of automobiles in their study. The thermal interaction of the driver with the ambient and his/her physiological reactions were examined by preparing a simulation model (manikin) in the test. Yiğit and Atmaca [15] worked on analytical and numerical solutions of models of environmental conditions and heat mass transfer, control mechanisms on human body. Akyol and Kaynakli [16] reported that standard air conditioning system was switched in an automobile parked in the sun and then the interior thermal conditions of the automobile were determined in detail during the 1$\mathrm{h}$ cooling period. During the period, relative humidity, air velocity, air and surface temperature measurements were taken at numerous locations in the automobile.

In that study, series of tests were conducted on two different automobiles. Atmaca and Yigit [17] approached effects of environmental parameters on comfort perceptions by means of experimentally obtained results and they criticized effects of these parameters on human health other than comfort perceptions. Cengiz and Babalı [18] conducted experiments with four different automobile driver seat surfaces on a real world road drive and with different test subject temperature measurements points in their work. Effects of thermal comfort are comparatively evaluated by means of objective measurements and subjective examinations. In another study of Babalık and Cengiz [19], reported results for measurements at the contact points of driver and the seat surface for the sake of thermal comfort. They measured skin temperature at eight different points, body humidity at two different points in the comfort tests in this study and they concluded that humidity is a more accurate scale for comfort evaluation rather than the skin temperature. Kaynaklı and Yamankaradeniz [20] developed computer software that provides various ease to the user in engineering applications, defines required procedures for determination of the thermal comfort level of the ambiance, calculates heat and mass transfer between body and environment by working on simulation of thermal comfort conditions given by instant energy balance model in their study.

Constituting a numerical mathematical model using artificial intelligence and fuzzy logic is aimed in this study. The model is for predicting the modified conventional vehicle AC system in respect of vehicle seat heating. Data were gathered from a previous experimental work in which a vehicle AC system was modified in order to acquire local heating or cooling in the vehicle seat. 


\section{Material and Method}

An out of usage Renault Toros SW model automobile was used in the experimental study. A vehicle AC was mounted on the vehicle. Automobile vehicle seat was modified particularly. Heater/cooler coils from thin tubes were mounted on the back and seat surfaces (cushions) of the driver seat in a way that the driver is not disturbed. The seat was heated/cooled by sending the refrigerant by means of a line from the $\mathrm{AC}$ to the coils. Refrigerant is distributed to the heater/cooler coils via a distributor manifold and then collected via a collector manifold. There is no adjustable heating-cooling option in the seat. Levels of the heating and cooling are only adjusted by the compressor speed.

Temperature values of the back and seating cushions of the seat were determined by measuring the temperatures with 5 thermocouples for each cushion and taking average of them. Additionally numerous temperature values such as coil inlet and outlet, evaporator inlet and outlet of the AC, compressor inlet and outlet were measured. Totally 22 different temperature measurements were done including the ambient air temperature measurement. Additionally compressor inlet and outlet pressures and compressor speed were measured separately and recorded.

Frontal view of the experimental setup is provided in Figure 1. The part numbers in the figure are explained as following.

1. Condenser fan

2. Inverter; AC / DC convertor

3. Electricity open close switches

4. Ambient temperature measurement

5. The manometer that measures compressor inlet and outlet temperatures

6. Seat heating or cooling activator switch

The rear view of the experimental setup is given in Figure 2. The part numbers in this view is explained as the following.

1. Direct current electrical motor

2. Compressor

3. Dryer

4. Condenser (for cooling) / Evaporator (for heating)

AC system is used for heating in winter season and cooling for summer season by means of a four way valve on the system. A schematic view of the experimental setup is provided in Figure 3. Some preliminary arrangements were done before each test run. First of all, AC installation was checked frequently for leakages that would lead to pressure drop. Thermocouples connected to the data logger were controlled if they were measuring the right values before each experiment.

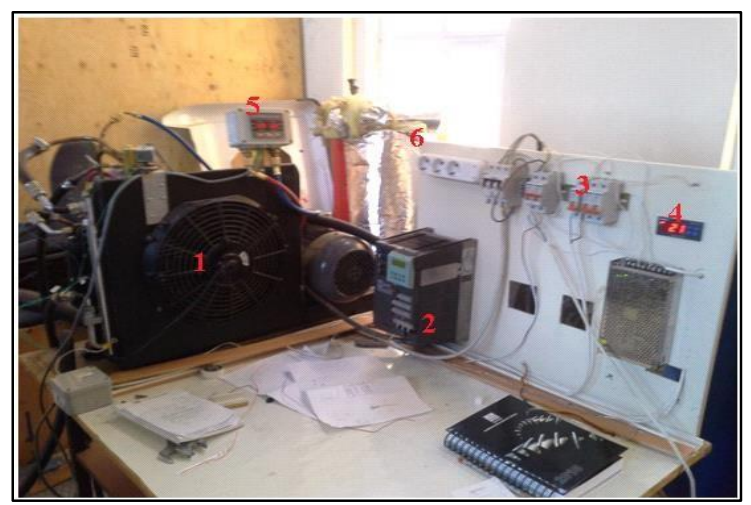

Figure 1. The frontal view of the experimental setup and the control panel

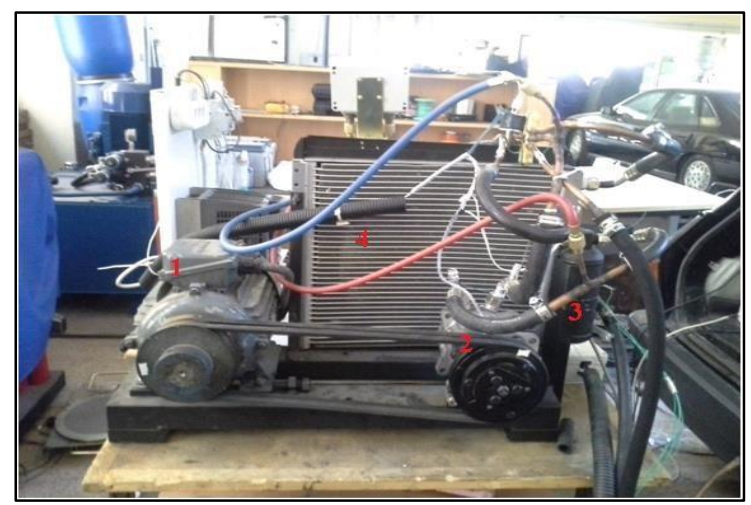

Figure 2. Rear view of the experimental setup

While a standard AC compressor is driven by the engine of the vehicle, compressor is driven by the DC electrical motor here. This drive speed is controlled by means of an inverter.

Data logger was set to take data samples at every five seconds. The system was operated for five minutes at idle conditions after data logger was connected to the computer which would record the measurements. Ten minutes time passed for each experiment in order to ensure that the system is operating in steady state conditions for each compressor speed. It is provided that the AC system reaches its steady state operation by which it can provide its best performance during this time limit. Data were recorded for fifteen minutes at each compressor speed step. Tests were repeated by placing a person on the seat after five minutes has passed from the initiation of this fifteen minute test for five minutes. Questions were subjected to the person on the seat about if he or she was comfortable in terms of thermal comfort. Voltage and current values of the electrical motor were measured and recorded at each test step. Also compressor inlet and outlet pressures were measured and recorded at every test step. 
Experiments were done between $500 \mathrm{rpm}$ to 1600 rpm by increasing the steps at $100 \mathrm{rpm}$.

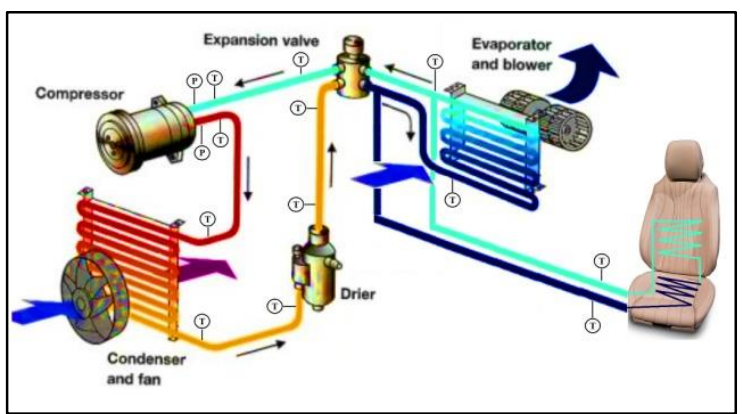

Figure 3. Schematic presentation of the experimental setup

As it can be understood from the Figure 3 in which the scheme of the experimental setup is provided, the seat was made to be heated by transferring the refrigerant coming from the conventional AC installation through the coil covering back and seating cushions of the seat. Human body heats up locally by the help of conduction heat transfer between the refrigerant and back and calf of the person sitting on the seat.

The heating installation scheme of the experimental setup is given in Figure 4. Condenser here is the seat of the vehicle since it is desired to be heated in this test. Pressure is decreased till evaporation pressure by passing through the expansion valve. The liquid refrigerant which's pressure is reduced reaches the evaporator and then evaporates. The refrigerant is pumped to condenser via compressor while its temperature and pressure are increasing. The refrigerant at the condenser condenses after release some of its heat energy through the seat and thus it heats the seat. He cycle continues as such (Figure 4 ).

Model of the system was constituted by means of fuzzy logic alongside of the experimental work in this study. MATLAB Fuzzy Logic Toolbox was utilized for the fuzzy logic model. The input parameters to the fuzzy logic are rotation speed (rev/min) and time (s) while output parameters are back temperature $\left({ }^{\circ} \mathrm{C}\right)$ and seat temperature $\left({ }^{\circ} \mathrm{C}\right)$. General structure of the fuzzy logic model prepared for the system is given in Figure 5.

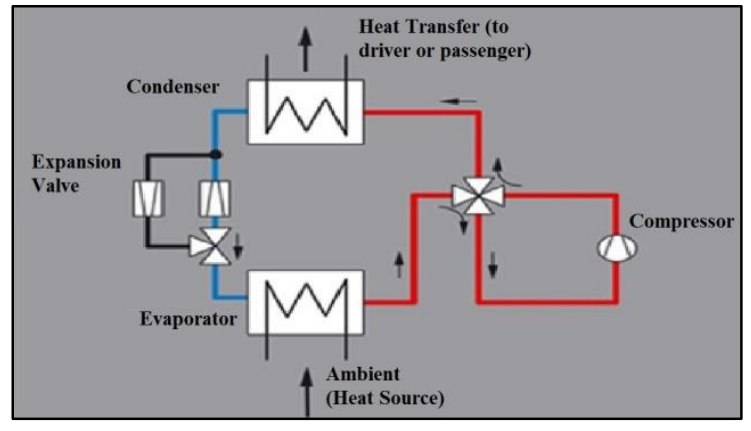

Figure 4. Heating installation scheme of the experimental system

The principal phases of constituting a fuzzy logic model by utilizing detected experimental data are fuzzyfication, forming the rule base, fuzzy inference mechanism and finally clarification. In the fuzzyfication task, the clear data gathered by the computer via measurements and input data that has a precise numerical value are converted into linguistic expressions or statements. At this stage, membership functions that are determined at the information base are used. Rules that define the relationship between input and output of the system are determined by using linguistic expressions obtained from the fuzzyfication. Fuzzy output is obtained in the fuzzy inference by using linguistic expressions and rules. Totally 120 supervision rules were defined. An external calculation was done in order to aid the decision making in determination of the supervision rules. If else loop was utilized in the external calculation after a decision matrix was formed for each output. The conversion process of the fuzzy outputs into clear outputs on the other hand is done at the clarification level [21]. The working principle of the fuzzy logic model is illustrated in Figure 6 [22]. Output values are obtained after the following steps are done; fuzzyfication process by the input membership functions, inference mechanism by the fuzzy logic rules and finally clarification by the output membership functions. MATLAB "evalfis" function was used in order to generate output variable sheet. Input was also provided to the workspace by means of a variable sheet. Totally 2160 back temperature values and 2160 seat temperature values that were measured for 180 time step x 12 rotation speed were also estimated by the fuzzy logic model. 


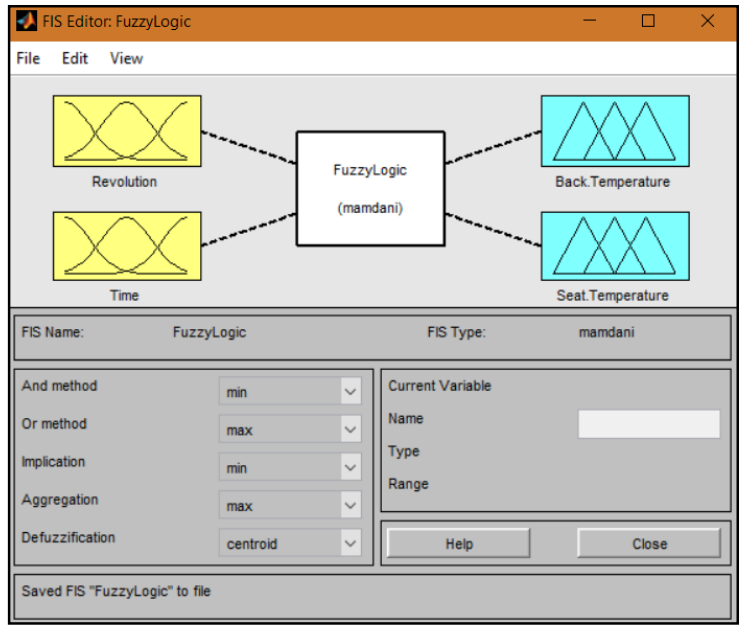

Figure 5. General structure of the fuzzy logic model prepared for the system

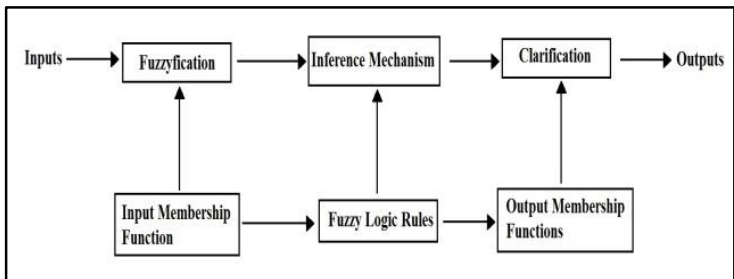

Figure 6. Working principle of the fuzzy logic

If an event can be defined with linguistic relationships then a Mamdani Fuzzy Logic Model (MFLM) can be constituted. MFLM uses relatively vast amount of rules [23]. Following equations can be viewed as the fuzzy propositions of MFLM [23].

$X=\left[x_{1}, \ldots, x_{2}\right]^{T}=\left[\begin{array}{cc}x_{11} & x_{12} \\ x_{21} & x_{22} \\ \vdots & \vdots \\ x_{n 1} & x_{n 1}\end{array}\right]$

$g=\left[g_{1}, \ldots, g_{n}\right]$

Here $T$ denotes transpose process. A general linguistic MFLM rule is given below:

$$
R_{i}: \text { if } x \text { is } A_{i} \text { then } y \text { is } B_{i}, i=1,2, \ldots, K
$$

Where $R_{i}$ is the number of the rule and $A_{i}$ and $B_{i}$ are fuzzy sets. $x$ is the real numeric input and $y$ is the numeric estimated output. A triangular membership function can be defined as follows:

$y=\operatorname{trim} f(x$, parameters $)$

$y=\operatorname{trimf}(x,[a b c])$ $f(x ; a, b, c)=\left\{\begin{array}{cc}0, & x \leq a \\ \frac{x-a}{b-a} & a \leq x \leq b \\ \frac{c-x}{c-b} & b \leq x \leq c \\ 0, & c \leq x\end{array}\right\}$

or compactly

$f(x ; a, b, c)=\max \left(\min \left(\frac{x-a}{b-a}, \frac{c-x}{c-b}\right), 0\right)$

The triangular fuzzy membership functions is defined by ( $a, b$, and $c$ ), where a and $c$ represent the minimum and maximum values, respectively, and $b$ is a value in between. Defuzzification is the process of taking the fuzzy outputs and converting them to a single or crisp output value. This process may be performed by any one of several defuzzification methods: Some common methods include the max or mean-max membership principles, the center-of-gravity method (centroid$\mathrm{COG}$ ), and the weighted average method. If $\mathrm{C}$ is the fuzzy set in question and $\mathrm{C}$ can be integrated, then the defuzzified value of $\mathrm{C}$ by this method is as in (8) [23].

$z^{*}=\frac{\int_{a}^{b} z C(z) d z}{\int_{a}^{b} C(z) d z}$

$a$ and $b$ here is an interval containing the support of $\mathrm{C}$ [23]. This kind of defuzzification determines $\mathrm{z}^{*}$ point as the middle of area.

The fuzzy sets and their corresponding numeric intervals are presented in Table 1. According to Table 1, Table 2 is arranged as a rule matrix. All rules in Table 2 were recorded in fuzzy engine with linguistic definition as in (3). "And" connections were used for each rule. The surface of the constituted fuzzy logic engine is presented for back temperature and seating temperature in Figure 7 and 8 respectively.

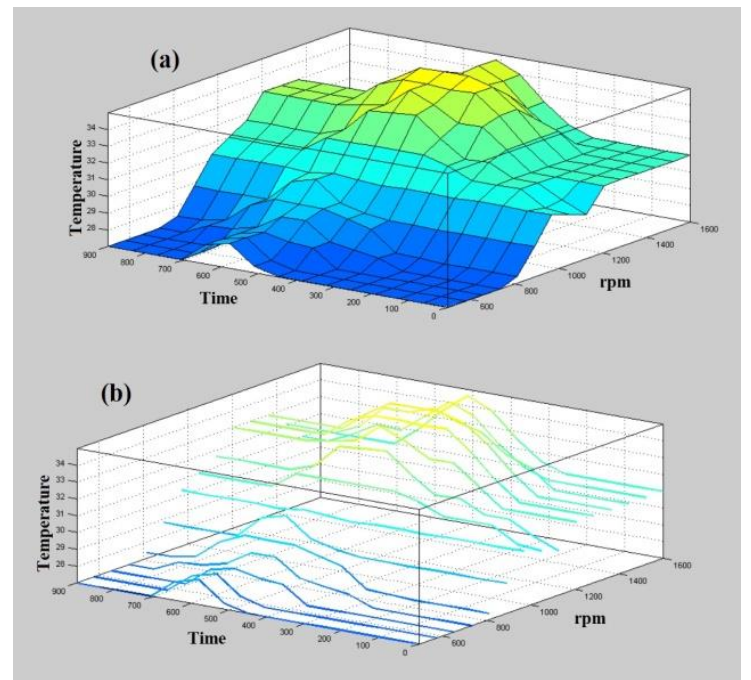

Figure 7. Back temperature surface of the fuzzy engine 


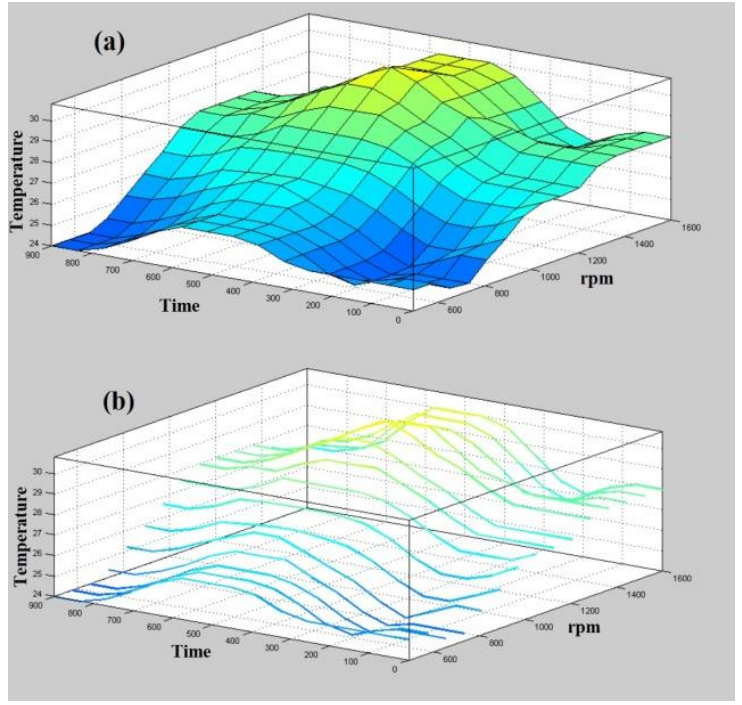

Figure 8. Seating temperature surface of the fuzzy engine
Figure 9 is provided in order to illustrate the membership function graphics and Figure 10 presents the output membership graphics. It should be mentioned here that fuzzy logic approach is a part of machine learning research. Machine learning also contains improved regression techniques such as Artificial Neural networks, optimization techniques such as Bird Flock, Bee Swarm and Ant Colony and statistical tools such as multi-regression techniques and mathematical modeling.

\section{Results and Discussion}

Air conditioning function is important in automobiles in respect of the thermal comfort. Standard AC of the automobiles is insufficient in very hot summer days or very cold winter days neither for the driver nor for the passengers.

Table 1. Fuzzy input and output sets

\begin{tabular}{|c|c|c|c|c|c|c|c|c|}
\hline & \multicolumn{2}{|r|}{ Revolution (rpm) } & \multicolumn{2}{|r|}{ Time $(\mathrm{s})$} & \multicolumn{2}{|c|}{ Back Temperature $\left({ }^{\circ} \mathrm{C}\right)$} & \multicolumn{2}{|c|}{ Seating Temperature $\left({ }^{\circ} \mathrm{C}\right)$} \\
\hline \multirow{12}{*}{ 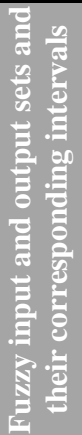 } & a & $: 500-600$ & a & $: 0-100$ & 1 & $: 23-27$ & 1 & $: 22-23$ \\
\hline & $\mathrm{b}$ & $: 500-700$ & $\mathrm{~b}$ & $: 0-200$ & 2 & $: 25-29$ & 2 & $: 22-24$ \\
\hline & c & $: 600-800$ & c & $: 100-300$ & 3 & $: 27-31$ & 3 & $: 23-25$ \\
\hline & d & $: 700-900$ & $\mathrm{~d}$ & $: 200-400$ & 4 & $: 29-33$ & 4 & $: 24-26$ \\
\hline & e & $: 800-1000$ & e & $: 300-500$ & 5 & $: 31-35$ & 5 & $: 25-27$ \\
\hline & $\mathrm{f}$ & : $900-1100$ & $\mathrm{f}$ & $: 400-600$ & 6 & $: 33-37$ & 6 & $: 26-28$ \\
\hline & $\mathrm{g}$ & $: 1000-1200$ & $\mathrm{~g}$ & $: 500-700$ & 7 & $: 35-39$ & 7 & $: 27-29$ \\
\hline & $\mathrm{h}$ & $: 1100-1300$ & $\mathrm{~h}$ & $: 600-800$ & & & 8 & $: 28-30$ \\
\hline & $\mathrm{i}$ & $: 1200-1400$ & $\mathrm{i}$ & $: 700-900$ & & & 9 & $: 29-31$ \\
\hline & $\mathrm{j}$ & $: 1300-1500$ & & $: 800-900$ & & & 10 & $: 30-32$ \\
\hline & $\mathrm{k}$ & $: 1400-1600$ & & & & & 11 & $: 31-32$ \\
\hline & 1 & $: 1500-1600$ & & & & & & \\
\hline
\end{tabular}
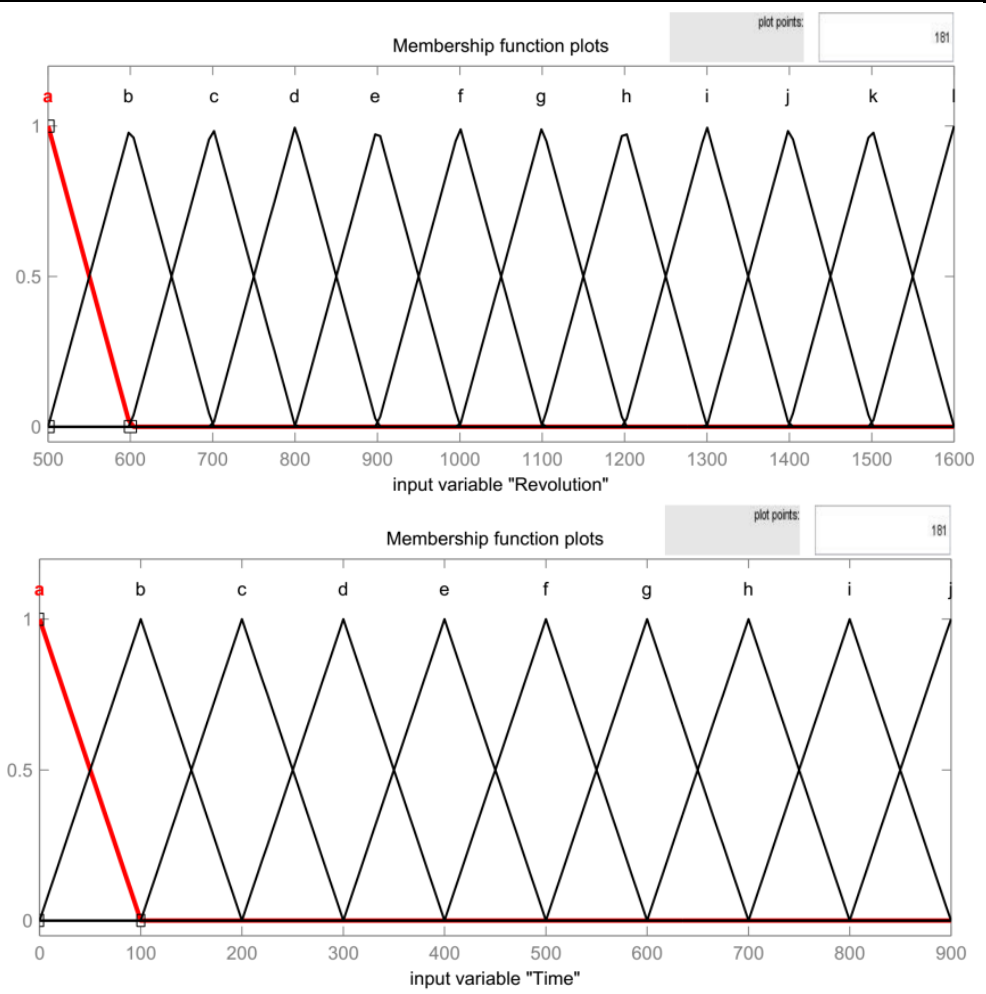

Figure 9. Graphics of input membership functions. 
Heating of the vehicle interior takes time at the startup of the engine in cold winter days. AC system is not operated generally for this time period for heating. Heating of the automobile cabin takes time after the $\mathrm{AC}$ is initiated for heating purposes. This means both time and energy loss. One can add thermal comfort inefficacy to this. An experimental investigation was conducted in order to modify local heating coil of the standard AC and to determine its performance and fuzzy logic model of the system was constituted using data of this experimental work.

Fuzzy cluster theory that is the first step of the fuzzy logic model as an alternative to the classical cluster theory was proposed [24]. There is no such thing that being a member of a certain cluster or not being a member. Instead it the membership level to a certain cluster is important. Statistical methods are used for engineering problems while assuming some assumptions and hence uncertainties are avoided by this way. However a mathematical or a statistical method cannot be used for every circumstance, a new method is needed for deterministic uncertainties. These uncertainties are defined as fuzzy and modeled as fuzzy [24]. Back and seat cushion temperatures are determined via fuzzy logic method in this study according to the rotation speed and time. Figure 11 and 12 show comparison of the experimental results of seat and back temperature changing versus rotation speed and time and data determined by the fuzzy logic. (Rotation speed $=500-1600$ $\mathrm{rpm} ; \mathrm{t}=5-900 \mathrm{~s})$. Totally 2160 back temperature values and 2160 seat temperature values that were measured for 180 time step x 12 rotation speed were also estimated by the fuzzy logic model. Being in accordance of fuzzy logic model results and experimental results is seen in Figure 11 and Figure 12. It is understood from the figures that heat transfer is realized from the live subject to the seat between fifth and tenth minutes. The comparison between experimental results and the fuzzy logic model results are achieved by correlation coefficient (R) and coefficient of determination $\left(\mathrm{R}^{2}\right)$.

Table 2. a-Rule matrix for back temperature; b-Rule matrix for seating temperature

\begin{tabular}{|c|c|c|c|c|c|c|c|c|c|c|c|c|c|}
\hline \multicolumn{2}{|c|}{$\mathbf{a}$} & \multicolumn{12}{|c|}{ Fuzzy sets for "Revolution" parameter } \\
\hline \multirow{7}{*}{ 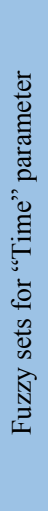 } & $\mathrm{a}$ & 2 & 2 & 2 & 2 & 3 & 4 & 3 & 4 & 4 & 4 & 4 & 4 \\
\hline & $\mathrm{b}$ & 2 & 2 & 2 & 2 & 3 & 4 & 4 & 4 & 4 & 4 & 4 & 4 \\
\hline & $\mathrm{c}$ & 2 & 2 & 2 & 2 & 3 & 4 & 4 & 4 & 4 & 4 & 4 & 4 \\
\hline & e & 2 & 2 & 2 & 3 & 3 & 4 & 5 & 5 & 6 & 6 & 5 & 5 \\
\hline & $\mathrm{f}$ & 2 & 2 & 3 & 3 & 3 & 4 & 5 & 6 & 6 & 6 & 6 & 6 \\
\hline & $\mathrm{g}$ & 3 & 3 & 3 & 3 & 4 & 4 & 5 & 5 & 6 & 6 & 5 & 5 \\
\hline & $\mathrm{h}$ & 2 & 2 & 2 & 3 & 3 & 4 & 4 & 5 & 5 & 5 & 5 & 4 \\
\hline \multirow{2}{*}{\multicolumn{2}{|c|}{ b }} & \multicolumn{12}{|c|}{ Fuzzy sets for "Revolution" parameter } \\
\hline & & $\mathrm{a}$ & $\mathrm{b}$ & $\mathrm{c}$ & $\mathrm{d}$ & $\mathrm{e}$ & $\mathrm{f}$ & $\mathrm{g}$ & $\mathrm{h}$ & $\mathrm{i}$ & $\mathrm{j}$ & $\mathrm{k}$ & 1 \\
\hline \multirow{5}{*}{ 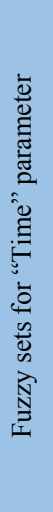 } & $\mathrm{a}$ & 4 & 4 & 3 & 4 & 5 & 6 & 6 & 6 & 7 & 7 & 7 & 7 \\
\hline & b & 4 & 4 & 3 & 4 & 4 & 5 & 6 & 6 & 7 & 7 & 7 & 7 \\
\hline & $\mathrm{c}$ & 4 & 3 & 3 & 3 & 4 & 5 & 6 & 6 & 7 & 7 & 6 & 6 \\
\hline & $\mathrm{d}$ & 4 & 4 & 4 & 4 & 5 & 6 & 7 & 7 & 8 & 7 & 7 & 7 \\
\hline & $\mathrm{e}$ & 5 & 5 & 5 & 5 & 6 & 7 & 8 & 8 & 9 & 9 & 9 & 9 \\
\hline
\end{tabular}


$R=\frac{n\left(\sum T_{E} T_{P}\right)-\left(\sum T_{E}\right)\left(\sum T_{P}\right)}{\sqrt{\left[n \sum T_{E}^{2}-\left(\sum T_{E}\right)^{2}\right]\left[n \sum T_{P}^{2}-\left(\sum T_{P}\right)^{2}\right]}}$

Here $T_{E}$ is the experimental data and $T_{P}$ is the predicted data.

Comparison of real data and values determined by fuzzy logic for back and seat temperatures via multi determination coefficient are provided in Figure 13 and Figure 14 respectively. The $\mathrm{R}^{2}$ value calculated for the back temperature is $83.47 \%$ while $\mathrm{R}^{2}$ value calculated for the seat temperature is $95.28 \%$. It is clearly seen that real values and the values estimated by the fuzzy logic model have correlation with each other.

Another advantage of the modeling with fuzzy logic is the usage of the model in order to estimate the intermediate values which were not tested during the experiments. Thermal performance was experimentally investigated for between 500 revolutions and 1600 revolutions by 100 revolutions increments in this study. Back and seat temperatures at $550 \mathrm{rev} / \mathrm{min}, 650 \mathrm{rev} / \mathrm{min}, 750$ $\mathrm{rev} / \mathrm{min}, 850 \mathrm{rev} / \mathrm{min}, 950 \mathrm{rev} / \mathrm{min}, 1050 \mathrm{rev} / \mathrm{min}$ $1150 \mathrm{rev} / \mathrm{min}, 1250 \mathrm{rev} / \mathrm{min}, 1350 \mathrm{rev} / \mathrm{min}, 1450$ $\mathrm{rev} / \mathrm{min}$ and $1550 \mathrm{rev} / \mathrm{min}$ were estimated utilizing fuzzy logic model. Comparison of the experimental results of back and seat temperature changing versus rotation speed and time and data estimated by the fuzzy logic for intermediate values of the parameters are given in Figure 15 and Figure 16 respectively. If the figure containing the estimations for back temperature is viewed, the estimated back temperature at $650 \mathrm{rpm}$ and $500^{\text {th }}$ second is higher than the experimental back temperature of $600 \mathrm{rpm}$ and $500^{\text {th }}$ second. However this estimated temperature is lower than the experimental back temperature at $700 \mathrm{rpm}$ and $500^{\text {th }}$ seconds (Figure 12).

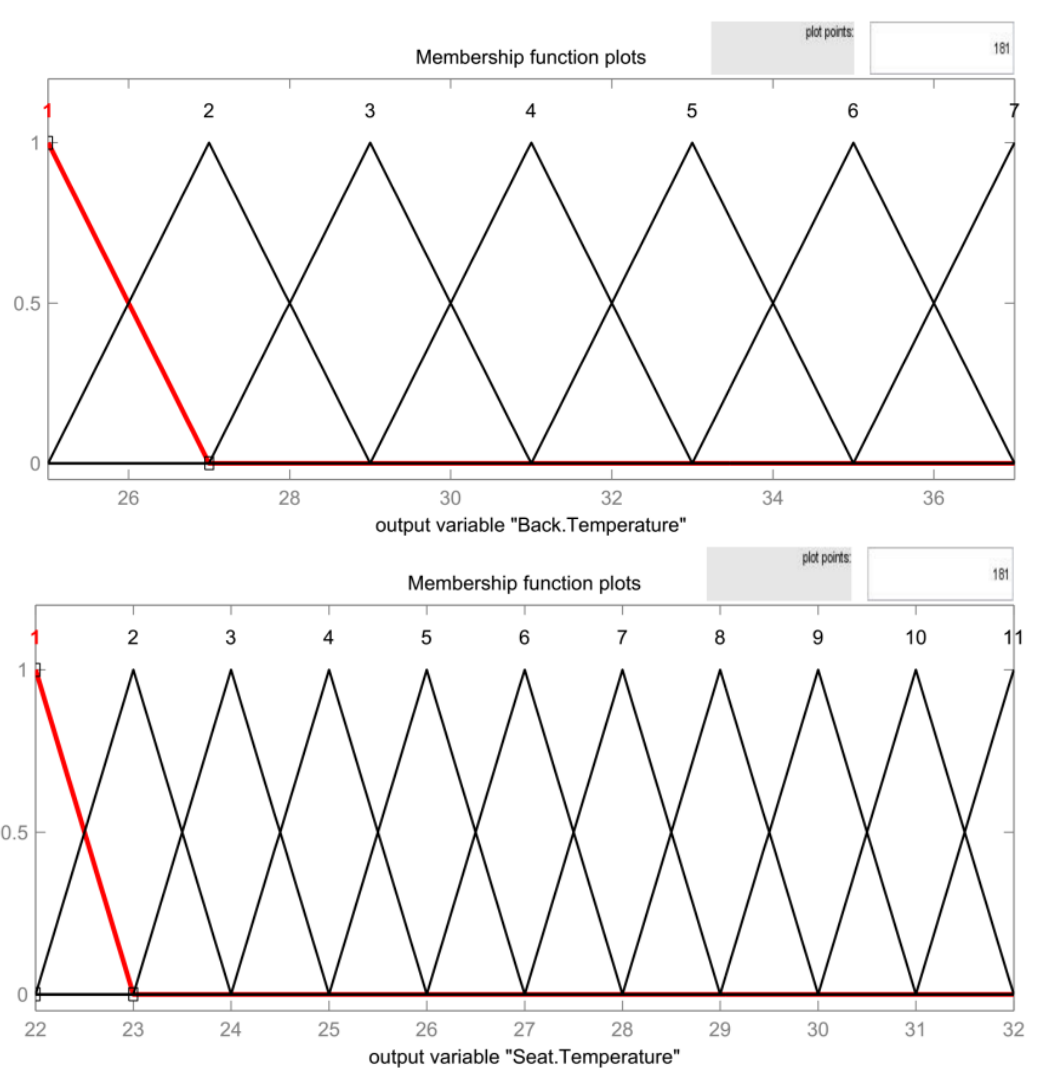

Figure 10. Graphics of output membership functions.

\section{Evaluation and Conclusion}

Local heating/cooling, namely seat heating/cooling system is more effective than the general AC. Hence time and energy consumption can be reduced by placing heating and cooling components in the vehicle seats. The body starts to cool down or heat up completely when the AC of the seat is initiated. The cooling or heating of the seat is achieved by means of the refrigerant circulated through the coils located in the seat. These coils are divided into two parts, one in the back of the seat and one in the seating cushion.

The highest temperatures on the surfaces of the seat are observed between $5^{\text {th }}$ and $10^{\text {th }}$ minutes of the experiments because of the heat transfer from the live test subject to the seat. The highest temperature is obtained for $1600 \mathrm{rpm}$ while the lowest temperature is obtained for $500 \mathrm{rpm}$. 


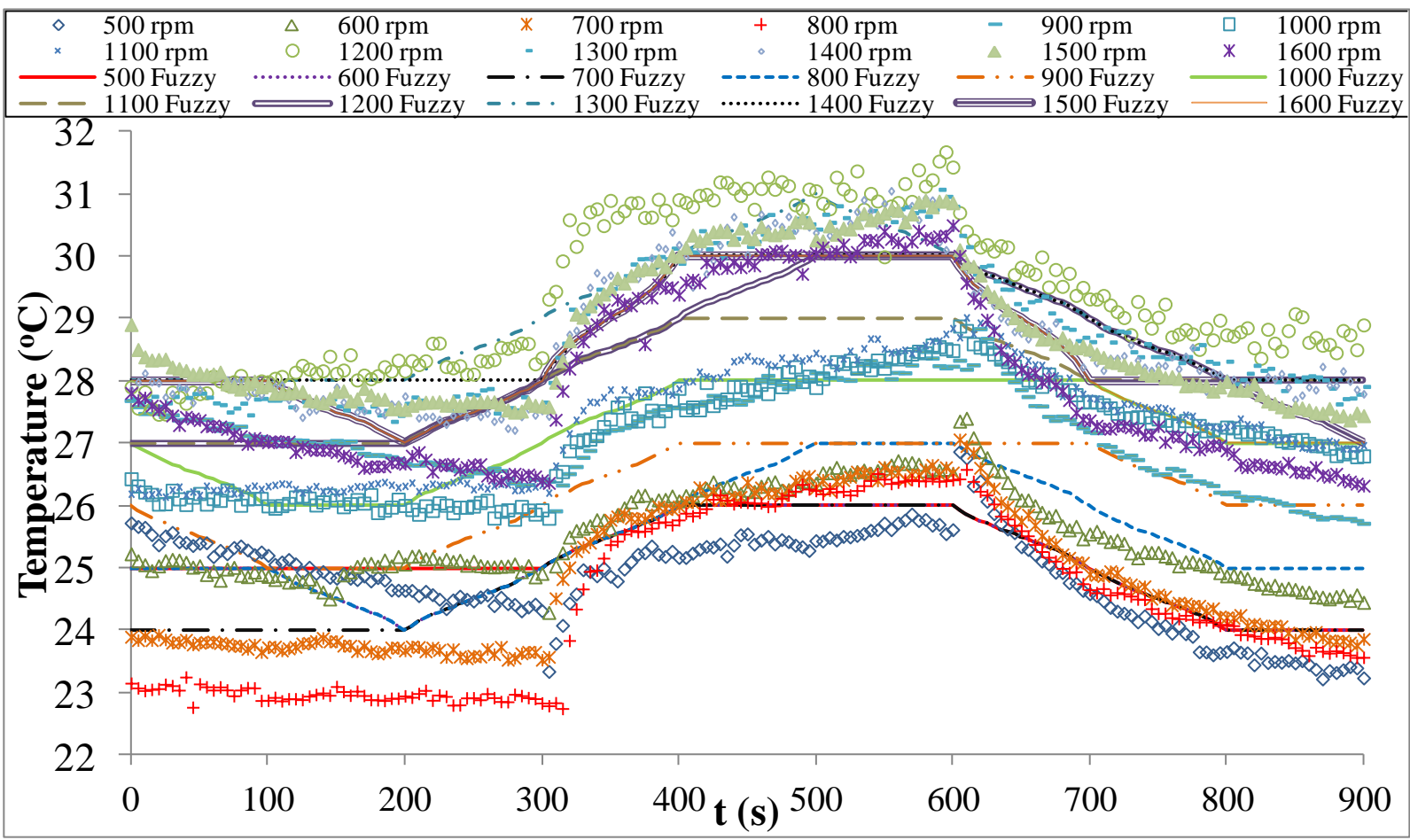

Figure 11. Comparison of the experimental results of seat temperature changing versus rotation speed and time and data determined by the fuzzy logic

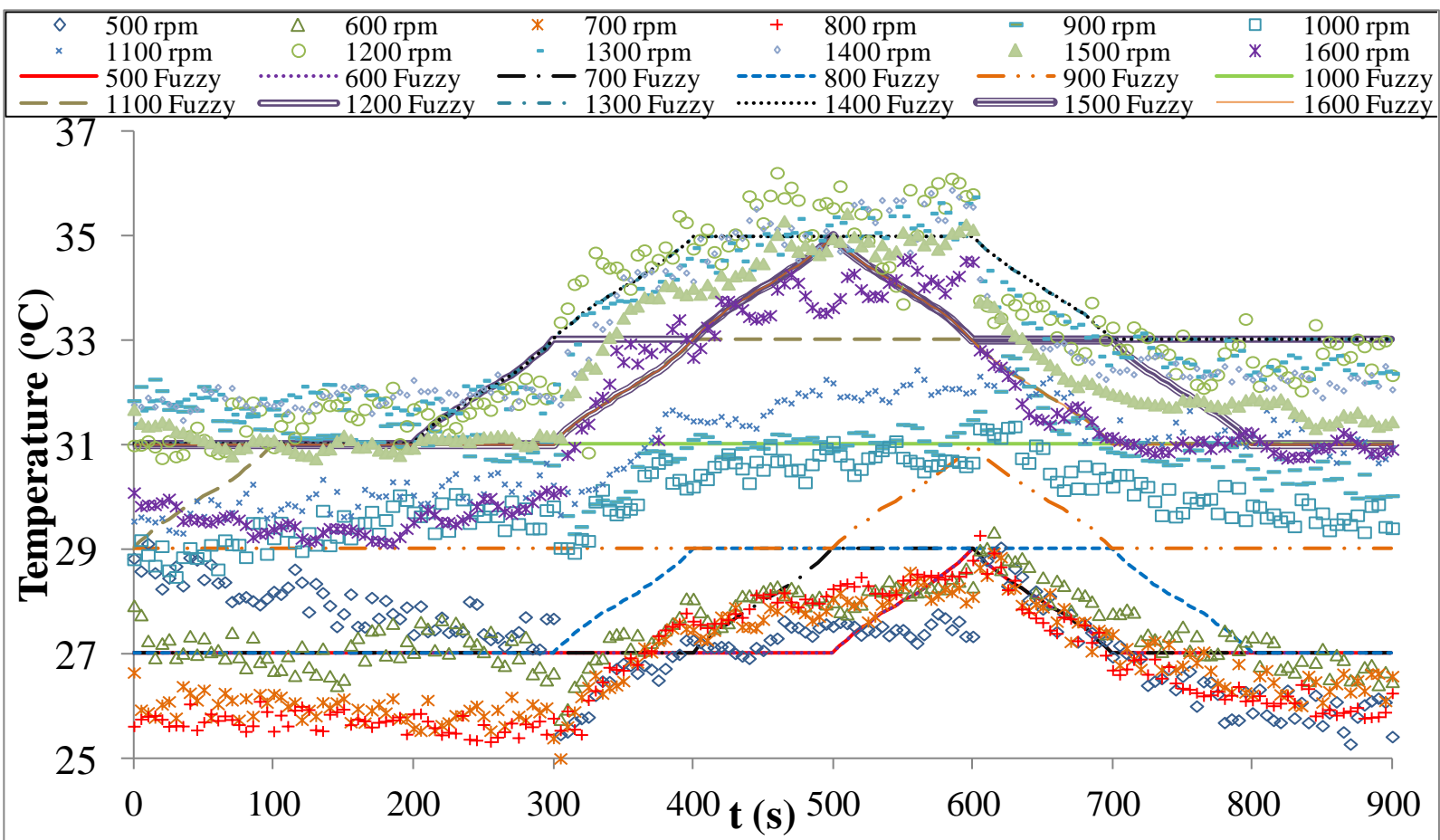

Figure 12. Comparison of the experimental results of back temperature changing versus rotation speed and time and data determined by the fuzzy logic 


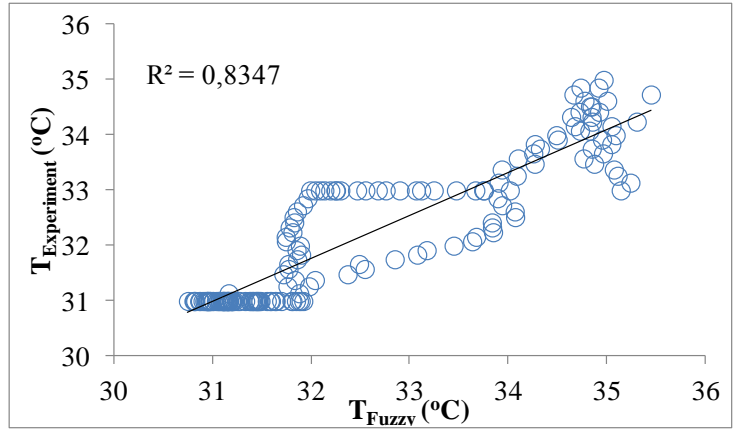

Figure 13. Comparison of real data and values determined by fuzzy logic by coefficient of determination and correlation coefficient for the back at $1500 \mathrm{rpm}$

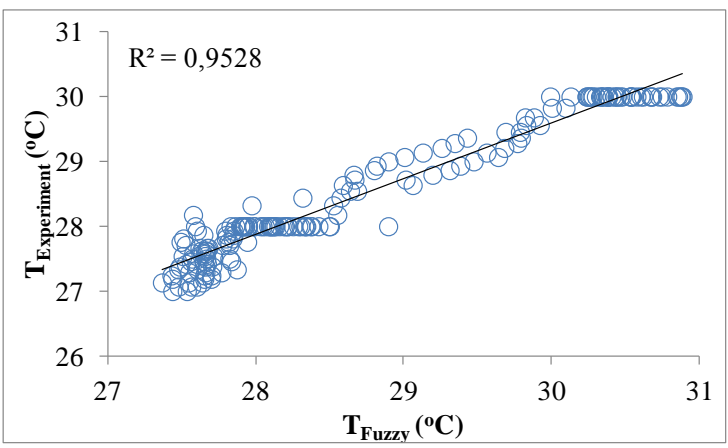

Figure 14. Comparison of real data and values determined by fuzzy logic by coefficient of determination and correlation coefficient for the seat at $1500 \mathrm{rpm}$
Fuzzy logic model was constituted by selected revolution and time as input parameters and back and seat temperatures as the output parameters. 2160 experimental test results were also found by the fuzzy logic model. Experimental data and data of the fuzzy logic model are compared by means of the determination coefficient method. After the highly correlated results of the fuzzy logic model, the model was used in order to determine the intermediate temperature values which were not tested during the experiments. Back and seat temperatures at $550 \mathrm{rev} / \mathrm{min}, 650 \mathrm{rev} / \mathrm{min}, 750$ $\mathrm{rev} / \mathrm{min}, 850 \mathrm{rev} / \mathrm{min}, 950 \mathrm{rev} / \mathrm{min}, 1050 \mathrm{rev} / \mathrm{min}$ $1150 \mathrm{rev} / \mathrm{min}, 1250 \mathrm{rev} / \mathrm{min}, 1350 \mathrm{rev} / \mathrm{min}, 1450$ $\mathrm{rev} / \mathrm{min}$ and $1550 \mathrm{rev} / \mathrm{min}$ that were not tested during the experimental work were estimated utilizing fuzzy logic model.

Temperature values for desired intermediate revolutions and time are obtained by the fuzzy logic model constitution that is planned in order to avoid any unwanted parameters in the experimental studies. As a main conclusion, fuzzy logic model is proposed as a successful tool that can be applied in order to determine the performance of the modified $\mathrm{AC}$ for the local heating of a vehicle seat. Still there are many other machine learning approaches for regression and optimization. These state-of-art methods are powerful when they used together. And fuzzy logic is no exception.

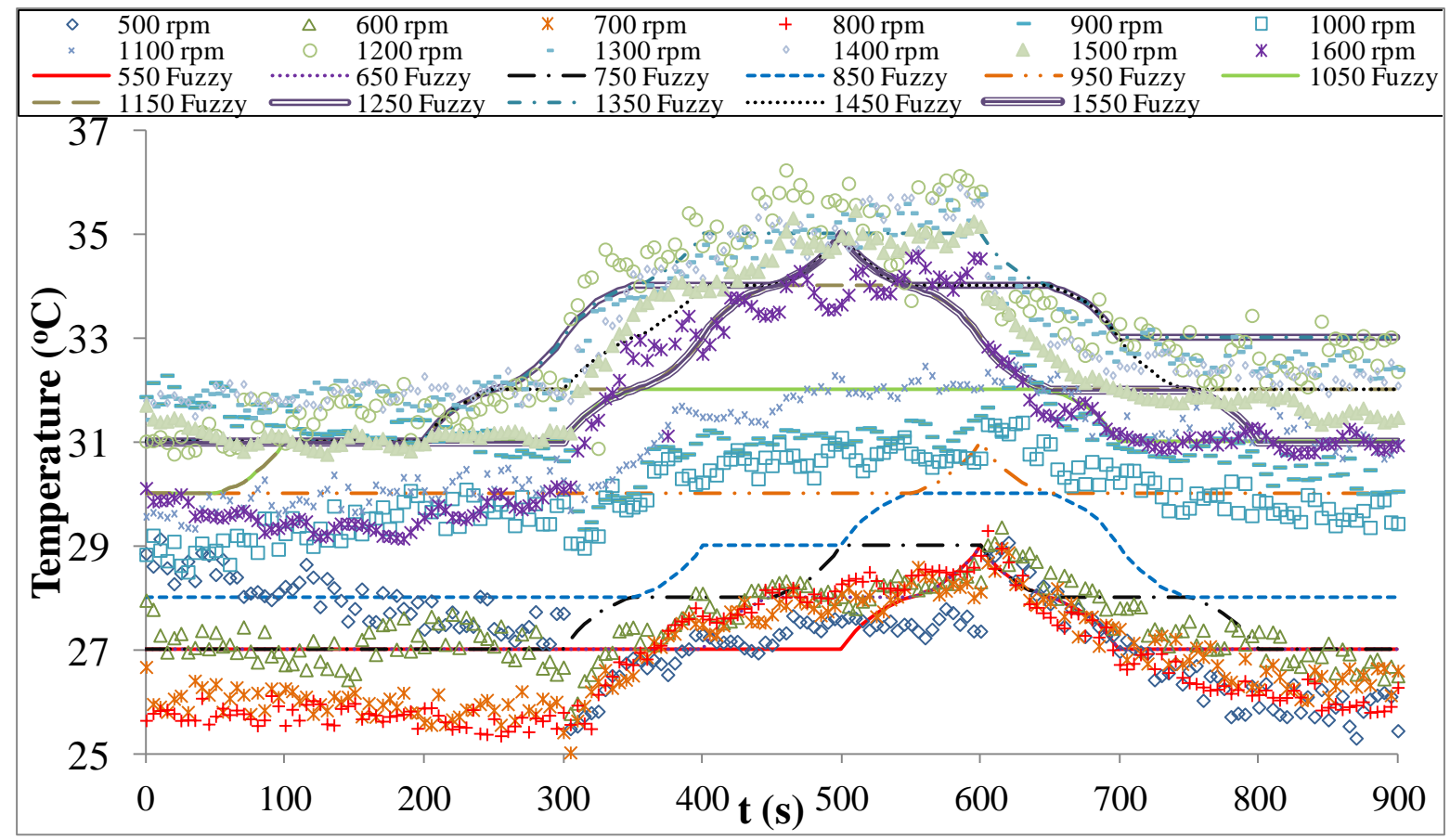

Figure 15. Comparison of the experimental results of back temperature changing versus rotation speed and time and data estimated by the fuzzy logic for intermediate values of the parameters 


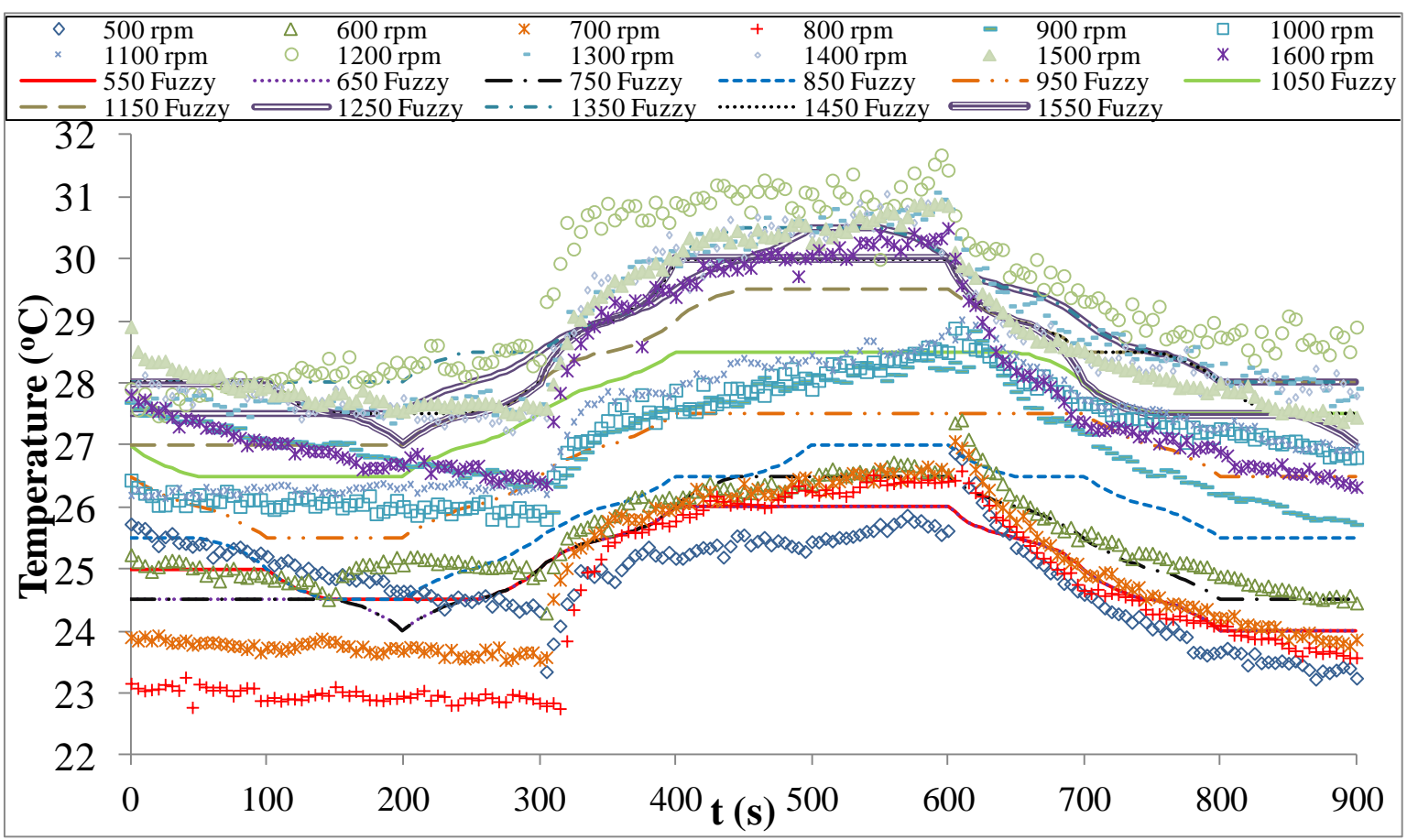

Figure 16. Comparison of the experimental results of seat temperature changing versus rotation speed and time and data estimated by the fuzzy logic for intermediate values of the parameters

\section{Acknowledgement}

This work is an intellectual product of the experimental study that was realized by the financial support of 11401028 numbered BAP research project funded by Selcuk University Research Funds. The support is greatly acknowledged.

\section{References}

[1] M. Mupit, and A.A. Shafie, "Experimental Study of Automated Car Power Window with Preset Position", APJES, vol. 3, no 1, pp. 21-28, 2015

[2] B. Hamed, and F. Alami, "Adaptive Hierarchical Fuzzy controller for HVAC Systems in Low Energy Buildings" APJES, vol. 3, no 2, pp. 01-07, 2015

[3] S. Akıncıoğlu, F. Mendi, A. Çiçek, and G. Akıncıoğlu, "Prediction Of Thrust Forces And Hole Diameters Using Artificial Neural Networks In Drilling Of AISI D2 Tool Steel With Cemented Carbide Tools", APJES, vol. 1, no2, pp. 11-20, 2013

[4] A. Guler, M.E. Berberler, and U.G. Nuriyev, “A New Genetic Algorithm for the 0-1 Knapsack Problem", APJES, vol. 4, no 3, pp. 09-14, 2016

[5] S. Öztürk, C. Karakuzu, M. Kuncan, and A. Erdil, "Fuzzy Neural Network Controller As A Real Time Controller Using Pso", APJES, vol. 5, no 1, pp. 15-22, 2017
[6] T.E. Kalayc1, "Construction And Implementation Of X3d Framework For Three Dimensional Graphics Software Using Artificial Intelligence Techniques", MSc Thesis, Ege Üniversitesi, İzmir, Turkey, 2006.

[7] Ç. Elmas, "Artificial Intelligence Applications", Seçkin Yayıncılık Publication, Ankara, Turkey, 2011.

[8] Ö. Hasgül, and A.S. Anagün, “Artificial Neural Network Usage In Analysis Of Experimental Results And An Application For Concrete Duration Test”, V. Ulusal Üretim Araştırmaları Symposium, İstanbul, Turkey, 2005.

[9] Ş. Ünal, T. Yımaz, E. Cihan, and O. Büyükalaca, "Coefficient of Performance Variation with the Mass Flow Rate for the Ejector Cooling System". Çukurova Üniversitesi Mühendislik Mimarlık Fakültesi Dergisi, vol. 28, no 1, pp. 6176, 2013.

[10] Ö. Solmaz, "Investigation of dynamic performance of a vehicle air-conditioning system driven by solar energy (PV)" Ph.D thesis, Selcuk University, Konya, Turkey, 2013.

[11] D. Erzurumlu, "Efficiency of air-conditioning system used in agricultural tractors on tractor performance and specific fuel comsumption", MSc Thesis, Çukurova Üniversitesi, Adana, Turkey, 2010.

[12] A. Alkan, and M. Hosoz, "Experimental Performance Of An Automobile Air Conditioning System Using A Variable Capacity Compressor For Two Different Types Of Expansion Devices", 
International Journal of Vehicle Design, vol. 52, no 1-4, pp. $160-176$

[13] K. Öngel, and H. Mergen, , "Review of literature about the effects of thermal comfort parameters on human body", Medical Journal of Suleyman Demirel University, vol. 16, no 1, pp. 2125, 2009

[14] M. Kılıç, and S.M. Akyol, "Experimental Investigation Of Thermal Comfort And Air Quality In An Automobile Cabin During The Cooling Period", Heat and Mass Transfer, vol. 48, no 8, pp. 1375-1384, August 2012

[15] Yiğit A, Atmaca İ. "Investigation of experimental change andcomparison with empirical results". TTMD VIII. Uluslararası Yapıda Tesisat Teknolojisi Sempozyumu, İstanbul, Turkey, 12-14 May 2008.

[16] M. Kilic, and O. Kaynakli, “An Experimental Investigation On Interior Thermal Conditions And Human Body Temperatures During Cooling Period In Automobile" Heat and Mass Transfer, vol. 47, no 4, pp. 407-418, April 2011

[17] İ. Atmaca, and A. Yiğit, "Predicting the effect of relative humidity on skin temperature and skin wettedness", Journal Of Thermal Biology, vol. 31, no 5, pp. 442-452, July 2006

[18] T.G. Cengiz, and F.C. Babalık, "An On-TheRoad Experiment Into The Thermal Comfort Of Car Seats", Applied Ergonomics, vol. 38, no 3, pp.
337-347, May 2007

[19] F.C. Babalık, and T.G. Cengiz, "Comfort Investigation By Measurements At Seat Driver Contact Points For Acclimated Seats" 11. Ulusal Ergonomi Congress, İstanbul, Turkey, 2004.

[20] Ö. Kaynaklı, and R. Yamankaradeniz, "Simulation Of Thermal Comfort Conditions By Instant Energy Balance Model", Frrat Üniversitesi Fen ve Müh. Bil. Dergisi, vol. 15, no 4, pp. 601612, 2003

[21] M. Tektaş, "Preparation Of Education Simulators Of Web Based Artificial Intelligence Techniques", Marmara Üniversitesi BAP Komisyonu Başkanlığı Proje Raporu, İstanbul, Türkiye, pp. 76-90, 2010

[22] Z. Y1lmaz, and Ş. Ocak, "Determination of Anemia via Fuzzy Logic", 1.Mühendislik ve Teknoloji Symposium, Ankara, Turkey, 2008.

[23] S. Ata, and K. Dincer, "Fuzzy logic modeling of performance proton exchange membrane fuel cell with spin method coated with carbon nanotube", International Journal of Hydrogen Energy, vol. 47, pp. 2626-2635, 2017.

[24] Y.Ş. Murat, and N. Uludağ, "Route Choice Modelling In Urban Transportation Networks Using Fuzzy Logic And Logistic Regression Methods" JSIR, vol. 67, no 1, pp. 19-27, January 2008 